\title{
Evaluation of anti-Bothrops asper venom activity of ethanolic extract of Brownea rosademonte leaves
}

\author{
MARCOS SALAZAR ${ }^{1,2}$ \\ LILIA CHÉRIGO ${ }^{2}$ \\ HILDAURA ACOSTA ${ }^{1}$ \\ RAFAEL OTERO \\ SERGIO MARTÍNEZ-LUIS ${ }^{4, *}$ \\ ${ }^{1}$ Centro de Investigación e Información \\ de Medicamentos y Tóxicos (CIIMET) \\ Facultad de Medicina \\ Universidad de Panamá \\ ${ }^{2}$ Facultad de Ciencias Naturales \\ Exactas y Tecnología \\ Universidad de Panamá \\ ${ }^{3}$ Facultad de Medicina \\ Universidad de Antioquia \\ Medellín, Colombia \\ ${ }^{4}$ Center for Biodiversity \\ and Drug Discovery \\ INDICASAT-AIP, Panama, Panama
}

Accepted June 20, 2014

\begin{abstract}
Significant inhibition of the coagulant and hemorrhagic effects of Bothrops asper venom was demonstrated by ethanolic extract prepared from the leaves of Brownea rosademonte. In vitro experiments preincubating $5.5 \mathrm{mg}$ of extract $\mathrm{kg}^{-1}$ b.m. for $30 \mathrm{~min}$ with a minimum hemorrhagic dose of venom $\left(273.8 \pm 16.1 \mu \mathrm{g}\right.$ of venom $\mathrm{kg}^{-1}$ b.m. $)$ lowered the hemorrhagic activity of the venom alone in CD-1 mice by $51.5 \pm 2.6 \%$. Additionally, $1.7 \mathrm{mg}$ extract $\mathrm{L}^{-1}$ plasma prolonged 5.1 times the plasma coagulation time. Fractionation of the extract led to the isolation of two compounds: ononitol (1) and quercetrin (2). The structure of compounds $\mathbf{1}$ and 2 was established by spectroscopic analyses, including APCI-HRMS and NMR $\left({ }^{1} \mathrm{H},{ }^{13} \mathrm{C}, \mathrm{HSQC}, \mathrm{HMBC}\right.$ and COSY). A quercetrin concentration of $0.11 \mu \mathrm{mol} \mathrm{L}-1$ prolonged the plasma coagulation time 2.6 times demonstrating that this compound was one of the active constituents of the Brownea rosademonte extract.
\end{abstract}

Keywords: Bothrops asper (Viperidae) venom, Brownea rosademonte (Caesalpinaceae), quercetrin, anticoagulant, antihemorrhagic, antiproteolytic, antihemolytic

Snakebite is a neglected public health problem in many tropical and subtropical countries worldwide. Close to 5 million snakebites occur every year, resulting in up to 2.5 million snakebite poisonings. Deaths of at least 100,000, many amputations and other permanent disabilities occur; most cases in Africa, Asia and Latin America. This health problem is often encountered among young people, children and farmers from poor rural settings with scarce medical resources (1-2).

Bothrops asper is mainly responsible (90\%) for snakebites in Panama (3), where about 2500 of such accidents occur every year, and for the incidence of 76 new cases per 100,000 inhabitants per year (4). Its venom induces conspicuous local effects (edema, hemorrhage, blisters, dermonecrosis, myonecrosis) and life-threatening systemic effects such as bleeding, defibrination, thrombocytopenia, cardiovascular shock and nephrotoxicity $(5,6)$. More

*Correspondence; e-mail: smartinez@indicasat.org.pa 
than 115 years after the beginning of serotherapy (7), antivenoms remain the only specific treatment for snakebites (8). Nevertheless, the lack of appropriate antivenom distribution and availability in distant rural places of tropical countries in Africa and Latin America has caused some snakebite victims to seek initial attention from traditional healers in their rural settings before their arrival to the hospital. Thus, they receive extracts of plants in many ways such as drinks, baths, steams and poultices, as reported by Otero et al. $(9,10)$ in Colombia. Plants could be a potential source for drug discovery in the treatment of neglected tropical diseases like snakebites. A proof is that over 700 plants have been reported in folk medicine for treating snakebites (11). These plants are an invaluable source for obtaining compounds that could be useful to inhibit some of the toxic effects caused by snakebites. Unfortunately, only a few plants have been evaluated in controlled bioassays and information regarding the isolation of active principles is very limited (11). Furthermore, the kinetics of the absorption, distribution, metabolism and excretion of plant extracts as well as their concentration in the tissue, are still unknown (12). Finally, controlled clinical trials in humans, using those plants or their isolated compounds, are not run due to many ethical bans.

In this work, an extract prepared from the leaves of Brownea rosademonte was tested for its neutralizing ability against the hemorrhagic, coagulant, hemolytic and proteolytic effects of $B$. asper venom from Panama.

\section{EXPERIMENTAL}

\section{Animals and venom}

CD-1 mice (50-70 days) weighing 18 to $19 \mathrm{~g}$ were used in the experiments. The animals were provided by the Biotery of the University of Panama (Panama City). The animals were kept in plastic cages under a $12 \mathrm{~h}$ light/ $12 \mathrm{~h}$ dark cycle at room temperature $\left(23 \pm 2{ }^{\circ} \mathrm{C}\right)$. The animals had free access to food and water. Experiments used the smallest possible number of animals and their suffering was avoided by using sevoflurane as general anesthetic. Animal care and the experimental protocol followed the international guiding principles for biomedical research involving animals.

Mice were divided into four groups of four mice (in duplicate) for use in hemorrhagic experiments as follows: group 1 (control mice treated only with venom), group 2 (mice treated only with plant extract), group 3 (control only with PBS), group 4 (mice treated with venom and plant extract).

The experiments involved the hemorrhagic effect of venom and venom neutralization by the extract. B. asper venom was obtained by milking more than 90 adult specimens of B. asper from four different geographic regions of Panama.

The venom was centrifuged at $3500 \times g$ for $30 \mathrm{~min}$, the supernatant was lyophilized and stored at $-40^{\circ} \mathrm{C}$ until used. Because of great similarity between B. asper and B. atrox venoms, the minimum inhibitory doses [minimum hemorrhagic dose (MHD), minimum coagulant dose (MCD), minimum indirect hemolytic dose (MIHD) and minimum proteolytic dose (MPD)] for each evaluated effect were determined based on the data previously reported for $B$. atrox venom (12-15). For the experiments, we used the respective reported minimum inhibitory doses plus two high and two low levels of venom (3, 2, 1, 0.5 and 0.3 MIHD). For 
example, the previously reported MIHD was $0.13 \mathrm{mg} \mathrm{L}^{-1}$. So, to detect the MIHD of our venom we employed test concentrations of $0.39,0.26,0.13,0.065$ and $0.04 \mathrm{mg} \mathrm{L}^{-1}$.

It is important to clarify that experiments carried out to determine the antihemorrhagic effect of $B$. rosademonte on mice are considered to be in vitro because the crude plant extract was preincubated together with venom before being injected to test mice.

\section{Plant collection and extract preparation}

B. rosademonte (Caesalpiniaceae) leaves were collected in the Parque Nacional Alto Chagres Panama; voucher specimens are deposited at the Herbarium of the University of Panama (Panama City, Panama). After sun drying fresh leaves and crushing them in a standard blender to obtain coarse powder, the extract was prepared by maceration with $96 \%$ ethanol for two days. Extract was concentrated to a semisolid paste using a rotary evaporator (Laborota 4010, Germany) to obtain $18.17 \mathrm{~g}$ of crude extract (6.2\% of plant yield) and stored at $-4{ }^{\circ} \mathrm{C}$ until used.

\section{Brine shrimp lethality assay}

In vitro lethality assay of Artemia salina extract was used to detect cell toxicity. Brine shrimp eggs were placed in seawater $[3.8 \%, m / V$, TetraMarine sea salt (United Pet Group, Inc., USA) in distilled water] and incubated at $28^{\circ} \mathrm{C}$. Eggs were hatched within $48 \mathrm{~h}$ providing a large number of larvae (nauplii). Ten nauplii were placed in each vial containing $5 \mathrm{~mL}$ of seawater and increasing concentrations of B. rosademonte extract (10, 50, 100, 500 and 1000 $\mu \mathrm{g} \mathrm{mL} \mathrm{m}^{-1}$. Each concentration was assessed in triplicate. Percentage of lethality was determined by comparing the mean number of surviving larvae of the test and control vials. $L C_{50}$ values were obtained from the best-fit line of plotted concentration vs. percentage of lethality. Potassium dichromate was used as a positive control in the bioassay while the negative control contained only the solvent (methanol) used for the preparation of test samples (16).

\section{Antihemorrhagic activity of the extract}

Groups were injected by intradermal route in the abdomen, one group with $5.5 \mathrm{mg}$ of plant extract $\mathrm{kg}^{-1} \mathrm{~b}$. $\mathrm{m}$. (group 2) and the other with one MHD of venom (venom controls) $\left(273.8 \pm 16.1 \mu \mathrm{g}\right.$ of venom $\mathrm{kg}^{-1} \mathrm{~b}$. m.) (group 1). In both cases, the solution was prepared in $0.1 \mathrm{~mL}$ phosphate buffered saline (PBS), $\mathrm{pH}$ 7.2. The control group (group 3) received PBS alone under identical conditions.

The plant extract $\left(5.5 \mathrm{mg}\right.$ of extract $\mathrm{kg}^{-1} \mathrm{~b}$. m.) was preincubated at $37^{\circ} \mathrm{C}$ for $30 \mathrm{~min}$ with one MHD of $B$. asper venom (273.8 $\pm 16.1 \mu$ g venom $\mathrm{kg}^{-1} \mathrm{~b}$. m.) dissolved in $0.1 \mathrm{~mL} \mathrm{PBS,}$ $\mathrm{pH}$ 7.2. Then, the mixture was injected i.d. into four mice (group 4). Two hours later, mice were sacrificed by sevoflurane inhalation, and the diameter of the hemorrhagic area was measured (12).

\section{Neutralization of the proteolytic activity of venom}

Proteolytic activity of $B$. asper venom $\left(10-250 \mu \mathrm{g} \mathrm{mL}^{-1}\right)$ was examined according to the method of Lomonte and Gutierrez with slight modifications (12) using $1 \%(\mathrm{~m} / \mathrm{V})$ casein as a substrate. For neutralization experiments, $800 \mu \mathrm{g}$ of $B$. rosademonte extract was preincubated for $30 \mathrm{~min}$ at $37^{\circ} \mathrm{C}$ with one $\mathrm{MPD}\left(81 \pm 5 \mathrm{U} \mathrm{mg}^{-1}\right)$ of $B$. asper venom. Casein $(2 \mathrm{~mL})$ in 
PBS pH 7.2 was then added to the mixture and again incubated for $30 \mathrm{~min}$ at $37^{\circ} \mathrm{C}$. The reaction was stopped by addition of $5 \%$ trichloroacetic acid. The mixture was centrifuged at $3500 \mathrm{xg}$ for $10 \mathrm{~min}$ and absorbance of the supernatant was measured at $280 \mathrm{~nm}$, in a Lambda 20 UV/VIS spectrometer (Perkin Elmer, USA). The experiment was repeated three times and results were expressed as mean $\pm \mathrm{SD}$.

\section{Neutralization of indirect hemolytic activity of venom}

The agarose-erythrocyte-egg yolk assay was used (14). Plant extract (25-1600 $\mu \mathrm{g})$ was tested against one MIHD $\left(195 \pm 7 \mu \mathrm{g} \mathrm{mL}^{-1}\right)$ of venom and the result was expressed as mean $\pm \mathrm{SD}$. The experiments were perfomed in duplicate.

\section{Neutralization of coagulant effect of venom}

Human plasma was used to assess the coagulant effect. Plasma was donated by the National Blood Bank (Panama City, Panama). The plasma came from healthy donors and complied with the Caja del Seguro Social (CSS, Panama National Hospital) requirements for use in biological experimentation and with permission from the donors. The method described by Theakston and Reid (18) was used with small modifications. Briefly, $1.0 \mu \mathrm{g}$ of B. asper venom dissolved in $50 \mu \mathrm{L}$ PBS, $\mathrm{pH} 7.2$, was added to human plasma $(0.3 \mathrm{~mL})$, preincubated at $37^{\circ} \mathrm{C}$ and the time required for plasma coagulation was determined. To evaluate the neutralizing capacity of the plant extract against the coagulant effect of venom, one $\operatorname{MCD}\left(1.7 \mu \mathrm{g} \mathrm{mL}^{-1}\right)$ of $B$. asper venom was dissolved in $50 \mu \mathrm{L}$ PBS, $\mathrm{pH} 7.2$, and preincubated at $37^{\circ} \mathrm{C}$ for $30 \mathrm{~min}$ with the plant extract ( 100 or $200 \mu \mathrm{g}$ ) and then, the mixture was added to human plasma $(0.3 \mathrm{~mL})$ and preincubated at $37^{\circ} \mathrm{C}$. The time required for plasma coagulation was determined (15).

\section{Chemical procedures}

NMR spectra were acquired on a Jeol Eclipse $400 \mathrm{MHz}$ spectrometer (Jeol, Japan) and referenced to residual solvent: ${ }^{1} \mathrm{H}$ and ${ }^{13} \mathrm{C}$ signals $\left[\delta_{\mathrm{H}} 3.34, \delta_{\mathrm{C}} 49.86\right.$ for $\mathrm{CD}_{3} \mathrm{OD}$ and $\delta_{\mathrm{H}} 2.54$, $\delta_{\mathrm{C}} 40.45$ for $\left(\mathrm{CD}_{3}\right)_{2} \mathrm{SO}$. APCIHR-MS were acquired on a JEOL LC-mate (Jeol) mass spectrometer.

Purification of the compounds was carried out by gel permeation column chromatography using Sephadex LH-20 (Sigma-Aldrich, USA) and column chromatography on silica gel 60 (0.063-0.210 mm, Merck, Germany). TLC (analytical) was performed on precoated silica gel 60 F254 plates (Merck). All solvents were of analytical reagent grade (ACS) grade and were used without further purification.

\section{Extraction and isolation of ononitol and quercetrin from B. rosademonte extract}

A portion of crude extract (10 g) was dissolved in a methanol/water mixture (90:10) and partitioned successively with ethyl acetate and hexane. All three fractions were evaporated to dryness using a rotar evaporator at low temperature $\left(30^{\circ} \mathrm{C}\right)$. Water fraction $(2.5 \mathrm{~g})$ was fractionated by gel permeation column chromatography using Sephadex LH-20 (50 g) and eluted with a methanol/water mixture (90:10, $V / V)$ for three days, giving 36 fractions. A 
major and active fraction (F4, $800 \mathrm{mg}$ ) was fractionated by column chromatography on silica gel $60(50 \mathrm{~g})$. The column was eluted with hexane, followed by a gradient of hexane/ $\mathrm{CHCl}_{3}(1: 0 \rightarrow 0: 1)$ and finally with a gradient of $\mathrm{CHCl}_{3} /$ methanol $(1: 0 \rightarrow 1: 1)$. Altogether, 10 secondary fractions (FI to FX) were obtained. Because of the low yield and high complexity of fractions, we proceeded to work with major fractions only. From major fraction FIII eluted with chloroform/methanol $(8: 2, V / V), 300 \mathrm{mg}$ of ononitol $(0.019 \%$ of plant yield, compound 1) was purified by re-crystallization (17). Fraction FVII (40 mg) was further subjected to silica gel 60 column chromatography and eluted with a gradient of hexane/chloroform $(1: 0 \rightarrow 0: 1)$ and chloroform/methanol $(1: 0 \rightarrow 1: 1)$. This process led to fifteen secondary fractions (F7-1 to F7-15). Fraction F7-9 eluted with $100 \%$ ethyl acetate was filtered and $12.1 \mathrm{mg}$ of quercetrin $(0.007 \%$ of plant yield, compound 2$)$ was obtained in the supernatant (18).

\section{RESULTS AND DISCUSSION}

Looking for alternatives to combat snakebites in Panama, we have chosen the leaves of $B$. rosademonte to evaluate their properties against some B. asper venom toxic effects. This plant is used by traditional healers and in a previous study its stem bark extract showed in vitro neutralizing ability against the lethal, hemorrhagic, edema formating, defibrinating and coagulant effects of B. atrox asper venom (15).

As a first step, we evaluated the lethality of crude extract against brine shrimp ( $A$. salina larvae) to verify the intrinsic toxicity of $B$. rosademonte. In the brine shrimp test, the plant extract showed an $L C_{50}$ above $1000 \mu \mathrm{g} \mathrm{mL}^{-1}$, suggesting the absence of cytotoxicity. The next step was to find the MHD, MCD, MIHD and MPD of venom. The lowest dose of venom that induced a hemorrhagic area of $10 \mathrm{~mm}$ in diameter in $2 \mathrm{~h}$ (mean $\pm \mathrm{SD}$ of three experiments) was $273.8 \pm 16.1 \mu \mathrm{g}$ venom $\mathrm{kg}^{-1} \mathrm{~b}$. m. Furthermore, we found that the plant extract did not produce any hemorrhagic effect in mouse tissue, this being another sign of the harmlessness of the plant. The MIHD of $B$. asper venom was $195 \pm 7 \mathrm{mg} \mathrm{L}^{-1}$. This dose induced a $20 \mathrm{~mm}$ diameter hemolysis halo after $20 \mathrm{~h}$ of incubation at $37^{\circ} \mathrm{C}$. MCD and MPD were $1.7 \pm 0.2 \mu \mathrm{g} \mathrm{mL}^{-1}$ and $81 \pm 5 \mathrm{U} \mathrm{mg}^{-1}$, respectively.

Once the minimum doses were determined, we proceeded to evaluate the effect of the plant against those caused by snake venom and it was found that ethanolic extract from the leaves of $B$. rosademonte had significant in vitro activity against coagulant and hemorrhagic effects provoked by $B$. asper venom at $5.5 \mathrm{mg} \mathrm{kg}^{-1} \mathrm{~b}$. m. significantly lowered $51.5 \pm$ $2.6 \%$ the hemorrhagic activity of $B$. asper venom (Fig. 1 ) and at $1.7 \mathrm{mg}$ extract $\mathrm{L}^{-1}$ plasma prolonged the plasma coagulation time induced by the venom until 5.1 times. This may indicate the possible inhibition of venom metalloproteinases responsible for local and systemic hemorrhage, as well as the thrombin-like enzymes of venom responsible for plasma coagulation by this plant extract. Ethanolic extract significantly prolonged the plasma coagulation time when preincubated with the venom (one microgram of venom-induced coagulation of human plasma in $30.1 \pm 1.5 \mathrm{~s}$ ). This effect was dose-dependent because 1.7 $\mathrm{mg}$ of extract $\mathrm{L}^{-1}$ of plasma showed a coagulation time of $155.3 \pm 2.4 \mathrm{~s}$, whereas $3.4 \mathrm{mg}$ of extract $\mathrm{L}^{-1}$ plasma delayed the coagulation time to $350.4 \pm 3.9 \mathrm{~s}(p<0.001)$. Proteolytic and indirect hemolytic activities of $B$. asper venom were not neutralized by the ethanolic extract prepared from the leaves of B. rosademonte. 

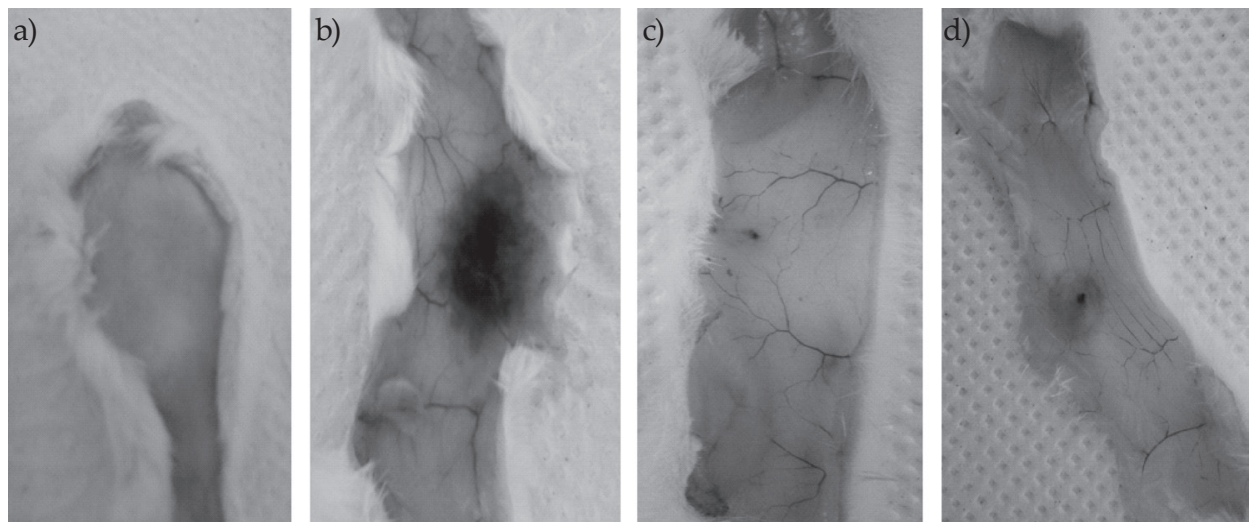

Fig. 1. Determination of the hemorrhagic effect of B. asper venom before and after B. rosademonte leaf ethanol extract administration: a) control (PBS, pH 7.2, and DMSO); b) 1 MHD of B. asper venom (273.8 $\pm 16.1 \mu \mathrm{g}$ of venom $\mathrm{kg}^{-1}$ b. m.); c) $5.5 \mathrm{mg}$ of B. rosademonte extract $\mathrm{kg}^{-1} \mathrm{~b}$. m.; d) $1 \mathrm{MHD}$ of B. asper venom $\left(273.8 \pm 16.1 \mu \mathrm{g}\right.$ of venom $\mathrm{kg}^{-1} \mathrm{~b}$. m.) and $5.5 \mathrm{mg}$ of plant extract $\mathrm{kg}^{-1} \mathrm{~b}$. $\mathrm{m}$.

\section{Chemistry}

Steroids, triterpenes, flavonoids and tannins were detected in the plant extract by TLC analysis (21).

Subsequent extract fractionation and compound purification were carried out by several chromatographic methods. These processes led isolation of two major components: ononitol (1) and quercetrin (2) from B. rosademonte (Fig. 2).

Compound 1 was isolated as a colorless crystalline solid. Its molecular formula was determined as $\mathrm{C}_{7} \mathrm{H}_{15} \mathrm{O}_{6}$ by APCI-HR-MS. The ${ }^{13} \mathrm{C}$ NMR spectrum for $\mathbf{1}$ (Table I) revealed 7 resonances, interpreted from the multiplicity-edited HSQC and DEPT (135 and 90) data as six methane and one methyl group. The ${ }^{1} \mathrm{H}$ NMR spectrum (Table I) showed three triplets (at $\delta_{\mathrm{H}} 3.59,3.57$ and $3.30 \mathrm{ppm}$ ), two doublets of doublets (at $\delta_{\mathrm{H}} 3.76$, and $3.71 \mathrm{ppm}$ ), a quartet (at $\delta_{\mathrm{H}} 4.08 \mathrm{ppm}$ ), and a singlet (at $\delta_{\mathrm{H}} 3.62 \mathrm{ppm}$ ). This evidence suggested that compound 1 was a cyclohexitol methyl ether. Based on detailed analysis of the spectroscopic data and<smiles>CO[C@H]1[C@@H](O)[C@H](O)[C@@H](O)[C@H](O)[C@H]1O</smiles>

Ononitol<smiles>C[C@@H]1O[C@H](Oc2c(-c3ccc(O)c(O)c3)oc3cc(O)cc(O)c3c2=O)[C@H](O)[C@@H](O)[C@@H]1O</smiles>

Quercetrin

Fig. 2. Chemical structures of major compounds isolated from B. rosademonte. 
comparison with the data reported by Vernon et al. (19), compound 1 was identified as ononitol.

Compound 2 was obtained as a yellow amorphous powder (m.p. $181-182^{\circ} \mathrm{C}$ ). The high resolution mass spectrum APCI (positive mode) showed a pseudo-molecular ion at $\mathrm{m} / \mathrm{z}$ $449.1079[\mathrm{M}+\mathrm{H}]^{+}$, corresponding to the molecular formula $\mathrm{C}_{21} \mathrm{H}_{21} \mathrm{O}_{11}$. The ${ }^{13} \mathrm{C}$ NMR spectrum (Table I) showed the presence of resonances characteristic of a flavonol core $\left(\delta_{\mathrm{C}}\right.$ 157.0, $134.8,178.1,161.9,99.2,164.8,94.3,157.5,104.7,121.6,116.2,149.0,145.8,116.0,121.2$ ppm). The ${ }^{1} \mathrm{H}$ NMR spectrum of 2 (Table I) showed two doublets at $\delta_{\mathrm{H}} 6.21$ and $6.40 \mathrm{ppm}$, indicating that the compound contained a 1,3 disubtituted aromatic ring A. Moreover, the resonances at $\delta_{\mathrm{H}} 7.36,7.30$ and $6.87 \mathrm{ppm}$ suggested the presence of a 1,3,4-trisubstituted aromatic ring B. In adition, two resonances at $\delta_{\mathrm{H}} 5.25\left(\mathrm{~d}, J=1.5 \mathrm{~Hz}, \mathrm{H}-1^{\prime \prime}\right)$ and $0.86 \mathrm{ppm}\left(\mathrm{d}, J=5.6 \mathrm{~Hz}, \mathrm{H}-6^{\prime \prime}\right)$ suggested the presence of a rhamnose unit in the structure of compound 2 . Based on the above evidence, the structure of $\mathbf{2}$ was defined as quercetrin. The structure of compound

Table I. NMR data for compounds isolated from B. rosademonte ${ }^{\text {a }}$

\begin{tabular}{|c|c|c|c|c|}
\hline \multirow{2}{*}{ Position } & \multicolumn{2}{|c|}{ Ononitol (in $\mathrm{CD}_{3} \mathrm{OD}$ ) } & \multicolumn{2}{|c|}{ Quercetrin (in DMSO- $d_{6}$ ) } \\
\hline & ${ }^{13} \mathrm{C}$ & ${ }^{1} \mathrm{H}$ & & \\
\hline 1 & 83.6 & $3.59(\mathrm{t}, 9.4)$ & & \\
\hline 2 & 71.2 & $4.08(\mathrm{q}, 3.8)$ & 157.0 & \\
\hline 3 & 70.7 & $3.71(\mathrm{dd}, 2.8)$ & 134.8 & \\
\hline 4 & 72.4 & $3.30(t, 9.4)$ & 178.1 & \\
\hline 5 & 73.0 & $3.57(t, 9.4)$ & 161.9 & \\
\hline 6 & 72.1 & $3.76(\mathrm{dd}, 2.8)$ & 99.2 & $6.21(\mathrm{~d}, 2.2)$ \\
\hline 7 & 59.5 & $3.62(\mathrm{~s})$ & 164.8 & \\
\hline 8 & & & 94.2 & $6.40(\mathrm{~d}, 1.8)$ \\
\hline 9 & & & 157.5 & \\
\hline 10 & & & 104.7 & \\
\hline $1^{\prime}$ & & & 121.6 & \\
\hline $2^{\prime}$ & & & 116.2 & $7.30(\mathrm{~d}, 1.8)$ \\
\hline $3^{\prime}$ & & & 149.0 & \\
\hline $4^{\prime}$ & & & 145.8 & \\
\hline $5^{\prime}$ & & & 116.0 & $6.87(\mathrm{~d}, 8.4)$ \\
\hline $6^{\prime}$ & & & 121.2 & $7.36(\mathrm{dd}, 8.1,1.8)$ \\
\hline $1^{\prime \prime}$ & & & 102.4 & $5.25(\mathrm{~d}, 1.5)$ \\
\hline $2^{\prime \prime}$ & & & 70.9 & $4.20(\mathrm{~m})$ \\
\hline $3^{\prime \prime}$ & & & 71.2 & $3.73(\mathrm{dd}, 9.2,3.4)$ \\
\hline $4^{\prime \prime}$ & & & 70.6 & $3.31(\mathrm{~m})$ \\
\hline $5^{\prime \prime}$ & & & 71.5 & $3.38(\mathrm{~m})$ \\
\hline $6^{\prime \prime}$ & & & 18.1 & $0.90(\mathrm{~d}, 6.6)$ \\
\hline
\end{tabular}

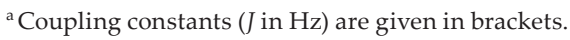


2 was confirmed by comparing our experimental data with those reported by Hanamura et al. (20).

Compounds 1 and 2 (with approximately $98 \%$ purity level) were tested against the hemorrhagic and coagulant activities of B. asper venom. Only compound 2 showed neutralizing capacity against the coagulant effect of venom. A concentration of $0.11 \mu \mathrm{mol} \mathrm{L}^{-1}$ of quercetrin prolonged the plasma coagulation time in the presence of $1 \mu \mathrm{g}$ of venom 2.6 times. Unfortunately, it was not possible to isolate other pure active compounds with the methodology used. However, we found out that highly polar fractions were those that showed the antihemorrhagic effect. This fact shows that highly hydroxylated compounds may be the main antihemorrhagic components of the plant.

\section{CONCLUSIONS}

Biological assessments performed with B. rosademonte ethanolic extract allowed us to demonstrate that this plant possesses significant activity in vitro against coagulant and hemorrhagic effects induced by $B$. asper venom. In the brine shrimp test, the organic extract of $B$. rosademonte showed no cytotoxicity $\left(L C_{50}\right.$ above $\left.1000 \mu \mathrm{g} \mathrm{mL} \mathrm{L}^{-1}\right)$. On the other hand, it was demonstrated that quercetrin is one of the major anti-coagulant compounds of that plant. To our knowledge, this is the first report on the isolation and structural characterization of some compounds produced by Brownea rosademonte.

Acknowledgments. - We are grateful to the Government of Panama (ANAM) for granting permission for plant collection. This work was supported by the National Secretariat for Science and Technology of Panama (SENACYT, grants APY-NI10-021 and COL06-017) and Panama University. Our thanks are due to SNI (SENACYT-Panama) for support to the authors [L. C. (SNI-28-2014) and S.M-L. (SNI-32-2014)]. Experiments were planned and conducted before the National Committee of Ethics in Research of Panama was established.

\section{REFERENCES}

1. J. M. Gutiérrez, D. Williams, H. W. Fan and D. A. Warrell, Snakebite envenoming from a global perspective: Towards an integrated approach, Toxicon 56 (2010) 1223-1235; DOI: 10.1016/j.toxicon.2009.11.020.

2. I. Pandolfi, D. Calzia, S. Ravera and A. Morelli, Inhibition of hemorrhagic snake venom components: old and new approaches, Toxins 2 (2010) 417-427; DOI: 10.3390/toxins2040417.

3. A. Quintero, El envenenamiento ofIdico en Panamá: epidemiología, fisiopatología y evaluación por el Laboratorio Clínico, Tecnomédica 1 (2000) 24-27.

4. A. Kasturiratne, A. R. Wickremasinghe, N. de Silva, N. K Gunawardena, A. Pathmeswaran, R. Premaratna, L. Savioli, D. G. Lalloo and H. J. de Silva, The global burden of snakebite: a literature analysis and modelling based on regional estimates of envenoming and deaths, PLoS Med. 5 (2008) e218; DOI: 10.1371/journal.pmed.0050218.

5. R. Otero, Epidemiological, clinical and therapeutic aspects of Bothrops asper bites, Toxicon $\mathbf{5 4}$ (2009) 998-1011; DOI: 10.1016/j.toxicon.2009.07.001.

6. R. Otero-Patiño, A. Segura, M. Herrera, Y. Angulo, G. León, J. M. Gutiérrez, J. Barona, S. Estrada, A. Pereañez, J. C. Quintana, L. J. Vargas, J. P. Gómez, A. Díaz, A. M. Suárez, J. Fernández, P. Ramírez, P. Fabra, M. Perea, D. Fernández, Y. Arroyo, D. Betancur, L. Pupo, E. A Córdoba, E. 
Ramírez, A. B. Arrieta, A. Rivero, D. C. Mosquera, N. L. Conrado and R. Ortiz, Comparative study of the efficacy and safety of two polyvalent, caprylic acid fractionated [IgG and F(ab')2] antivenoms, in Bothrops asper bites in Colombia, Toxicon 59 (2012) 344-355, DOI: 10.1016/j.toxicon.2011.11.017.

7. C. Bon, The serum-therapie was discovered 100 years ago, Toxicon 34 (1996) 142-143; DOI: 10.1016/0041-0101(96)83647-6.

8. E. Hansson, S. Cuadra, A. Oudin, K. de Jong, E. Stroh, K. Torén and M. Albin, Mapping snakebite epidemiology in Nicaragua-Pitfalls and possible solutions, PLoS Negl Trop Dis. 4 (2010) e896; DOI: 10.1371/journal.pntd.0000896.

9. R. Otero, G. S. Tobón, L. F. Gómez, R. G. Osorio, R. Valderrama, D. Hoyos, E. Urreta, S. Molina and J. Arboleda, Accidente ofídico en Antioquia y Chocó. Aspectos clínicos y epidemiológicos (marzo de 1989-febrero de 1990), Acta Med. Colomb. 17 (1992) 229-249.

10. R. Otero, S. L. Jiménez and R. Fonnegra, Plantas Utilizadas contra Mordedura de Serpiente en Antioquia y Choco, Colombia, 1. ed. 2000, Editorial Grancolor, Medellin 2000, pp. 402.

11. W. B. Mors, M. C. Nascimento, B. M. Pereira and N. A. Pereira, Plant natural products active against snake bite--the molecular approach, Phytochemistry 55 (2000) 627-642; DOI: 10.1016/S00319422(00)00229-6.

12. R. Otero, V. Núñez, J. Barona, R. Fonnegra, S. L. Jiménez, R. G. Osorio, M. Saldarriaga and A. Díaz, Snakebites and ethnobotany in the northwest region of Colombia. Part III: neutralization of the haemorrhagic effect of Bothrops atrox venom, J. Ethnopharmacol. 73 (2000) 233-241; DOI: 10.1016/ S0378-8741(00)00321-4.

13. R. Otero, R. Fonnegra, S. L. Jiménez, V. Núñez, N. Evans, S. P. Alzate, M. E. García, M. Saldarriaga, G. Del Valle, R. G. Osorio, A. Díaz, R. Valderrama, A. Duque and H. N. Vélez, Snakebites and ethnobotany in the northwest region of Colombia: Part I: traditional use of plants, J. Ethnopharmacol. 71 (2000) 493-504; DOI: 10.1016/S0378-8741(00)00243-9.

14. R. Otero, V. Núñez, S. L. Jiménez, R. Fonnegra, R. G. Osorio, M. E. García and A. Díaz, Snakebites and ethnobotany in the northwest region of Colombia: Part II: neutralization of lethal and enzymatic effects of Bothrops atrox venom, J. Ethnopharmacol. 71 (2000) 505-511; DOI: 10.1016/S03788741(99)00197-X.

15. V. Núñez, R. Otero, J. Barona, M. Saldarriaga, R. G. Osorio, R. Fonnegra, S. L. Jiménez, A. Díaz and J. C. Quintana, Neutralization of the edema-forming, defibrinating and coagulant effects of Bothrops asper venom by extracts of plants used by healers in Colombia, Braz. J. Med. Biol. Res. 37 (2004) 969-977; DOI: 10.1590/S0100-879X2004000700005.

16. L. Cherigo, J. Lezcano, C. Spadafora and S. Martínez-Luis, Evaluation of phytotoxic, cytotoxic and antiparasitic in vitro activities of Borreria verticillata, a weed of Panamanian coffee crops. Biosci. Res. 9 (2012) 82-86.

17. B. Lomonte and J. M. Gutierrez, la actividad proteolitica de los venenos de serpientes de Costa Rica sobre la caseina, Rev. Biol. Trop. 31 (1983) 37-40.

18. R. D. G. Theakston and H. A. Reid, Development of simple standard assay procedures for the characterization of snake venoms, Bull. World Health Org. 61 (1983) 949-956.

19. D. M. Vernon, M. C. Tarczynski, R. G. Jensen and H. J. Bohnert, Cyclitol production in transgenic tobacco, Plant J. 4 (1993) 199-205; DOI: 10.1046/j.1365-313X.1993.04010199.x.

20. T. Hanamura, T. Hagiwara and H. Kawagishi, Structural and functional characterization of polyphenols isolated from acerola (Malpighia emarginata DC.) fruit, Biotech. Bioch. 69 (2005) 280-286; DOI: 10.1271/bbb.69.280. 